\title{
Rediscovery of the endangered lichen Pseudocyphellaria aurata (Lobariaceae, Ascomycota) in mainland Spain
}

\author{
Ibai OLARIAGA ${ }^{1}$, Graciela PAZ-BERMÚDEZ ${ }^{2}$, Javier CALVO ${ }^{3}$, Javier ETAYO ${ }^{4}$, María PRIETO ${ }^{5 *}$ \\ 1,5 Department of Biology and Geology, Physics and Inorganic Chemistry, Rey Juan Carlos University, Calle Tulipán s.n., 28933 Móstoles, Madrid, Spain. \\ ${ }^{2,3}$ Universidade de Vigo, Escola de Enxeñaría Forestal, Departamento ERNMA, A Xunqueira s.n., 36005 Pontevedra, Spain. \\ ${ }^{4}$ Navarro Villoslada 16, $3^{\circ}$ dcha., E-31003 Pamplona, Navarra, Spain. \\ *Correspondence: maria.prieto@urjc.es \\ ${ }^{1}$ https://orcid.org/0000-0002-0334-7750, ${ }^{2}$ https://orcid.org/0000-0003-3724-8483, ${ }^{3}$ https://orcid.org/0000-0002-1732-9449, \\ ${ }^{4}$ https://orcid.org/0000-0003-0392-0710, ${ }^{5}$ https://orcid.org/0000-0002-1692-9821
}

\begin{abstract}
Lichens, as well as other organisms, should be considered important biodiversity components for the establishment of priorities in conservation biology. In this study, we report six new recent localities of the highly endangered, epiphytic macrolichen Pseudocyphellaria aurata in Spain: two in Navarra and four in A Coruña. Previous Spanish reports based on literature and herbarium specimens suggest a reduction of the distribution area of P. aurata and local extinction. Pseudocyphellaria aurata is known to be extinct in six localities, where it has not been observed since the middle of the $19^{\text {th }}$ century (Cádiz, Pontevedra, Málaga). Four records reported for central Spain (Zaragoza, Salamanca, Teruel) are considered unplausible. The newly discovered populations are located in well-preserved patches of atlantic deciduous forest with strong oceanic influence, whose long-term ecological stability seems evident because of the presence of ancient trees. Nevertheless, these populations are small, fragmentary, and are threatened by habitat degradation, forestry and maybe fungal pathogens. Two populations, Intzola and Beba (Navarra and A Coruña, respectively), account for $75.7 \%$ of thalli. The localities with the highest number of trees colonized by $P$. aurata are Santa Leocadia and Beba in A Coruña. We reassessed the conservation status of this species concluding that conservation initiatives must be implemented to avoid its extinction in mainland Spain.
\end{abstract}

Keywords. Conservation biology, IUCN, local extinction, red-listing.
Resumen. Los líquenes son una parte importante de la biodiversidad que debería tenerse en cuenta para establecer prioridades en la biología de la conservación. En este estudio, se citan 6 nuevas localidades en las que el líquen epífito Pseudocyphellaria aurata, gravemente amenazado, ha sido hallado recientemente: 2 localidades en Navarra y 4 en A Coruña. Registros bibliográficos y especímenes de herbario previos sugieren que $P$. aurata ha sufrido una regresión en su área de distribución. Se considera $P$. aurata extinta en 6 localidades en las que no se ha observado desde mediados del siglo XIX (Cádiz, Pontevedra, Málaga). Cuatro citas del centro peninsular (Zaragoza, Salamanca, Teruel) no se consideran plausibles. Todas las nuevas localidades albergan manchas bien conservadas de bosque atlántico, en lugares con fuerte influencia oceánica y con presencia de árboles centenarios que sugieren continuidad ecológica. Sin embargo, las poblaciones de P. aurata descubiertas son pequeñas, fragmentadas, y están amenazadas por degradación de hábitat, explotación forestal y quizás, hongos patógenos. Dos poblaciones, Intzola y Beba (Navarra y A Coruña, respectivamente), albergan el 75,7 \% de los talos. Las localidades en las que se han contabilizado más árboles colonizados por $P$. aurata son Santa Leocadia y Beba en A Coruña. Con los datos recopilados, evaluamos el estado de conservación de $P$. aurata, concluyendo que deben de implementarse iniciativas de conservación para evitar su extinción en la España peninsular.

Palabras clave. Biología de la conservación, extinción local, IUCN, listas rojas.

How to cite this article: Olariaga I., Paz-Bermúdez G., Calvo J., Etayo J., Prieto M. 2020. Rediscovery of the endangered lichen Pseudocyphellaria aurata (Lobariaceae, Ascomycota) in mainland Spain. Anales del Jardín Botánico de Madrid 77: e099. https://doi.org/10.3989/ajbm.2558

Title in Spanish: Redescubrimiento del líquen amenazado Pseudocyphellaria aurata (Lobariaceae, Ascomycota) en la España peninsular.

Associate Editor: Isabel Martínez. Received: 18 April 2020; accepted: 7 October 2020; published online: 4 January 2021.

\section{INTRODUCTION}

Although numerous threats are currently affecting global biodiversity, lichens are often overlooked when establishing priorities for conservation biology (IUCN 2015). Given the importance of epiphytic lichens in many forest ecosystems (Hayward \& Rosentreter 1994), and their value as indicators of environmental changes and climatic conditions (Benítez \& al. 2012; Matos \& al. 2015), these organisms should be considered in conservation initiatives. In order to evaluate the conservation status of lichen species, a deep understanding of the ecology and distribution of the target species is required (Scheidegger \& Werth 2009).
The family Lobariaceae includes foliose macrolichens mostly associated with well-preserved forest ecosystems. The whole family, although not yet formally listed in the IUCN Red List, has been proposed for Global Red Listing because the majority of its species are probably threatened (Baillie \& al. 2004). Pseudocyphellaria aurata (Ach.) Vain. is probably one of the most threatened species of Lobariaceae in continental Europe and has been included in a number of national and regional red lists (e.g., Woods \& Coppins 2012; Kon \& Ohmura 2014; Roux \& al. 2016). With a cosmopolitan distribution in tropical areas of the world (Galloway 1998), P. aurata is also found in drier, warmer, coastal areas in cool temperate regions 
(Galloway \& Arvidsson 1990). In Europe, P. aurata is a rare species reported from Great Britain, France, Italy, Portugal, and Spain (Degelius 1935; Nimis \& Martellos 2017), whereas the records from Switzerland are considered doubtful (Nimis 1993). European populations of $P$. aurata have been stated to be in decline in France (Roux \& al. 2016) and Great Britain (Smith \& al. 2009), and to be extinct in Italy (Nimis \& Martellos 2017), but the general state of the populations remains unknown in Europe (Serusiaux 1989) including the Iberian Peninsula. In their revision of Iberian Lobariaceae, Burgaz \& Martínez (1999) cited material from 10 localities in Portugal, but one single from Spain (Carballal \& al. 1985), collected in 1978 (SANT-Lich. 133) in Fragas do Eume Natural Park (A Coruña). Despite visiting this locality several times, $P$. aurata has not been found there again (López de Silanes, pers. comm).

The presence of Pseudocyphellaria aurata in mainland Spain prior to the report by Carballal \& al. (1985) is enigmatic. Although quite a few reports exist, no specimens or recent observations have been made since the $19^{\text {th }}$ century and it is unclear whether bibliographic reports of $P$. aurata can be attributed to misidentifications. Pseudocyphellaria aurata has been reported from Andalusia (Colmeiro 1867; Jovet 1941) and the French Basque Country (Jovet 1941). During his doctoral thesis, Etayo (1989) searched for $P$. aurata, intensively in Navarra without success, and that led Etayo (2002) to consider it extinct in the Western Pyrenees. However, more recent finds in southern France (Vivant 1988) and in the Pyrénées Atlantiques department (Roux \& al. 2016), not far from the boundary with Spain, support the possibility that $P$. aurata is present in the Spanish Pyrenees.

During fieldwork in the Western Pyrenees and Galicia, Pseudocyphellaria aurata was found in six new localities and was also rediscovered in the same locality from which Jovet (1941) reported it more than 80 years ago, $500 \mathrm{~m}$ from the Spanish border. Since $P$. aurata is a threatened species for which very little updated information exists, the main goal of this study was to compile all the information available about its presence in mainland Spain. These data are of paramount importance to assess the conservation status of $P$. aurata under the IUCN criteria, not only in Spain, but also in Europe, and indispensable for its inclusion in conservation initiatives.

\section{MATERIAL AND METHODS}

Pseudocyphellaria aurata was searched for in lowland oceanic localities with well-preserved deciduous forests with ancient trees, in A Coruña, Biscay, Cádiz, Gipuzkoa, Málaga and Navarra. The number of thalli and trees colonized by $P$. aurata were counted at each locality. Accompanying species were identified following Smith \& al. (2009) for lichenized fungi and Casas \& al. (2006, 2009) for mosses and liverworts. Nomenclature follows Index Fungorum as a rule. Exceptions are Arthonia pelvetii (Linds.) H. Olivier (placement in Homostegia Fuckel not accepted, a genus with perithecioid ascomata) and P. aurata (placecement in Crocodia Link not accepted). As for the latter, the latest phylogenetic hypothesis of Lobariaceae (Moncada \& al. 2013) does not resolve the relationships among lineages assigned to Pseudocyphellaria s.l., so far a morphologically well recognizable genus. Thus, we consider it premature to split Pseudocyphellaria into several smaller genera. This avoids unnecessary changes if the monophyly of Pseudocyphellaria s.l. is demonstrated by future phylogenetic analyses.

Coordinates are provided in decimal format (WGS84). For each new species occurrences, the exact locality, approximate elevation above sea level, annual precipitation and temperature were recorded. Climatic data were obtained from Meteogalicia (www.meteogalicia.gal/observacion/rede/ redeIndex.action?request_locale $=\mathrm{gl}$ ) and Meteorología y Climatología de Navarra (http://meteo.navarra.es/estaciones/ mapadeestaciones.cfm) webpages. Annual mean temperature and annual precipitation were calculated based on all available data from the nearest station to each site and located at a similar altitude. Herbarium specimens were examined either by loaning herbarium specimens (H-Ach), during visits to herbaria (PC, I. Olariaga) or by viewing high-quality scans (MAF-Lich, PC) when available. Material from Bertiz (Navarra) and Intzola populations (Navarra) of $P$. aurata is deposited in ARAN-Fungi fungarium (Thiers 2020).

\section{RESULTS}

Pseudocyphellaria aurata has been found in six new localities in Spain, two in Navarra (Bertiz, Intzola) and four in A Coruña (Albariña, Beba, Devesa de Anllares, Santa Leocadia), and was also re-discovered in the French Pyrenean locality (Intzola, French Basque Country) cited by Jovet (1941). However, $P$. aurata was searched for without success in Canuto del Risco Blanco (Los Barrios, Cádiz), La Sauceda (Cortes de la Frontera, Málaga), Inpernuko erreka (Etxalar, Navarra), Endarlatsa erreka (Lesaka-Irun, NavarraGipuzkoa), Altzolarats erreka (Aia-Zestoa, Gipuzkoa) and many other valleys from Navarra and Basque Country. A list of the new populations of $P$. aurata, with detailed descriptions of the sites, number of trees colonized, number of thalli, accompanying species and conservation threats, is provided below. In addition, a list of previous localities reported in the literature or supported by herbarium specimens is given.

\section{New localities}

A summary of the newly discovered localities, with the number of thalli and trees colonized by $P$. aurata and phorophytes, is provided in Table 1. Localities are represented on a map (Fig. 1). Populations in which more thalli were counted are Intzola and Beba, with 97 and 60 thalli respectively, which account for $73 \%$ of thalli found in this study. Populations with the highest numbers of colonized trees were Santa Leocadia and Beba, with 10 and 9, respectively. In Intzola, the population with the highest number of thalli, $P$. aurata was found only on three trees. Although $P$. aurata was found on several, mostly acid-barked, tree species, Castanea sativa Mill. and Quercus robur L. were 
Table 1. Newly found populations and subpopulations of the epiphytic macrolichen Pseudocyphellaria aurata in Spain. Coordinates, number of thalli, trees colonized, height at which thalli grew, and phorophytes are provided.

\begin{tabular}{|c|c|c|c|c|c|c|c|c|}
\hline Province & Pop. & Subp. & Coord. & Thalli & $\begin{array}{l}\text { Trees } \\
\text { Col. }\end{array}$ & Orient. & $\begin{array}{l}\text { Height } \\
\text { (m) }\end{array}$ & Phorophyte \\
\hline Navarra & & Ber2 & $43.161839-1.611640$ & 4 & 2 & - & $6-8$ & Alnus glutinosa \\
\hline $\begin{array}{l}\text { Navarra/ Pyrenées } \\
\text { Atlantiques }\end{array}$ & Intzola & Int 1 & $43.318772-1.673708$ & 10,23 & 2 & $\mathrm{~N}$ & $1-3$ & Quercus robur \\
\hline \multirow[t]{2}{*}{ A Coruña } & $\begin{array}{l}\text { La Devesa de } \\
\text { Anllares }\end{array}$ & An1 & $42.946339-9.079122$ & 31 & 7 & S-SW & $1-1.6$ & Quercus robur \\
\hline & & & Subtotal & 31 & 7 & & & \\
\hline \multirow[t]{2}{*}{ A Coruña } & Albariña & $\mathrm{Alb}$ & $42.928357-8.740161$ & 1 & 1 & $\mathrm{~S}$ & 1.9 & Castanea sativa \\
\hline & & & Subtotal & 1 & 1 & & & \\
\hline \multirow{2}{*}{ Beba } & & Beb4 & $42.892014-9.010208$ & 11 & 1 & SW & $0.7-1.7$ & Castanea sativa \\
\hline & & & Subtotal & 68 & 8 & & & \\
\hline \multirow[t]{5}{*}{ A Coruña } & $\begin{array}{l}\text { Santa } \\
\text { Leocadia }\end{array}$ & SL1 & $42.899644-8.922139$ & $1,1,1,1,2,2$ & 6 & SW & $0.7-1.3$ & Corylus avellana, Laurus nobilis \\
\hline & & SL2 & $42.899869-8.922097$ & 2,2 & 2 & SW & $0.9-1.2$ & Quercus robur, Corylus avellana \\
\hline & & SL3 & $42.897581-8.924231$ & 4,3 & 2 & SW & $1.7-2.3$ & Quercus robur \\
\hline & & & Subtotal & 19 & 10 & & & \\
\hline & & & Total & 222 & 32 & & & \\
\hline
\end{tabular}

the most common phorophytes (Table 1) on which P. aurata colonizes mostly mossy bark in rather sun-exposed situations. Remarkably, P. aurata was also found on an allochthonous planted Platanus hispanica Mill. ex Münchh. tree.

1. Albariña, Negreira, A Coruña, Galicia, 200 m, 2301 $1 / \mathrm{m}^{2}, 12.3^{\circ} \mathrm{C}$ (Paramos station). This is a small stand of deciduous forest, mainly with Castanea sativa, located along Albariña stream and surrounded by Eucalyptus plantations. Accompanying species were Normandina pulchella (Borrer) Nyl., Nephroma tangeriense (Maheu \& A.Gillet) Zahlbr., Pannaria conoplea (Ach.) Bory, Parmeliella triptophylla (Ach.) Müll.Arg., and Sticta limbata $(\mathrm{Sm}$.) Ach. Other lichen species observed in the trees around were Leucodermia leucomelos (L.) Kalb and Lobarina scrobiculata (Scop.) Nyl.

2. Beba, Mazaricos, A Coruña, Galicia. 250 m, 2243 1/ $\mathrm{m}^{2}, 12.2^{\circ} \mathrm{C}$ (Coto Muíño station). This well-preserved forest is located along a tributary stream of Xallas river but is threatened because of the surrounding Eucalyptus and Pinus plantations. Main tree species are Castanea sativa, Corylus avellana L., Crataegus monogyna Jacq., Quercus robur, and Sambucus nigra L. Pseudocyphellaria aurata was detected in four spots along Beba stream, growing on bark of standing trees and mostly in the south or southeast aspects. Four subpopulations were found at this locality (Table 1): Beba 1 , with one and four thalli in two Quercus robur trees together with Parmeliella triptophylla. Lobarina scrobiculata, Pectenia plumbea (Lightf.) P.M.Jørg., L. Lindblom, Wedin \& S. Ekman, Sticta fuliginosa (Dicks.) Ach., and Teloschistes flavicans (Sw.) Norman were observed in surrounding trees. Beba 2, with most of the thalli colonized by the lichenicolous fungus Arthonia pelvetii (Hepp. ex Linds.) H.Olivier (Fig. 2a), which might affect their survival. One Sambucus tree hosted 20 thalli from the base up to a height of c. $3 \mathrm{~m}$, accompanied by Leucodermia leucomelos, Nephroma tangeriense, and Pectenia plumbea, whereas another tree had 10 thalli of $P$. aurata growing together with Nephroma tangeriense and Sticta limbata. The thalli growing on a mossy Sambucus nigra tree were not parasitized. Beba 3, with most of the thalli also infected by Arthonia pelvetii, which may affect the future of this subpopulation. Main accompanying species were Nephroma laevigatum Ach. and Sticta fuliginosa. Finally, Beba 4, with accompanying species Lobarina scrobiculata, Nephroma laevigatum, and Sticta fuliginosa.

3. Devesa de Anllares, Negreira, A Coruña, Galicia, ca. $270 \mathrm{~m}, 22431 / \mathrm{m}^{2}, 12.2^{\circ} \mathrm{C}$ (Coto Muíño station). This is a very well-preserved forest along the Xallas river that lacks a protection figure and is highly threatened due to the surrounding Eucalyptus plantations and the construction of mini hydropower 


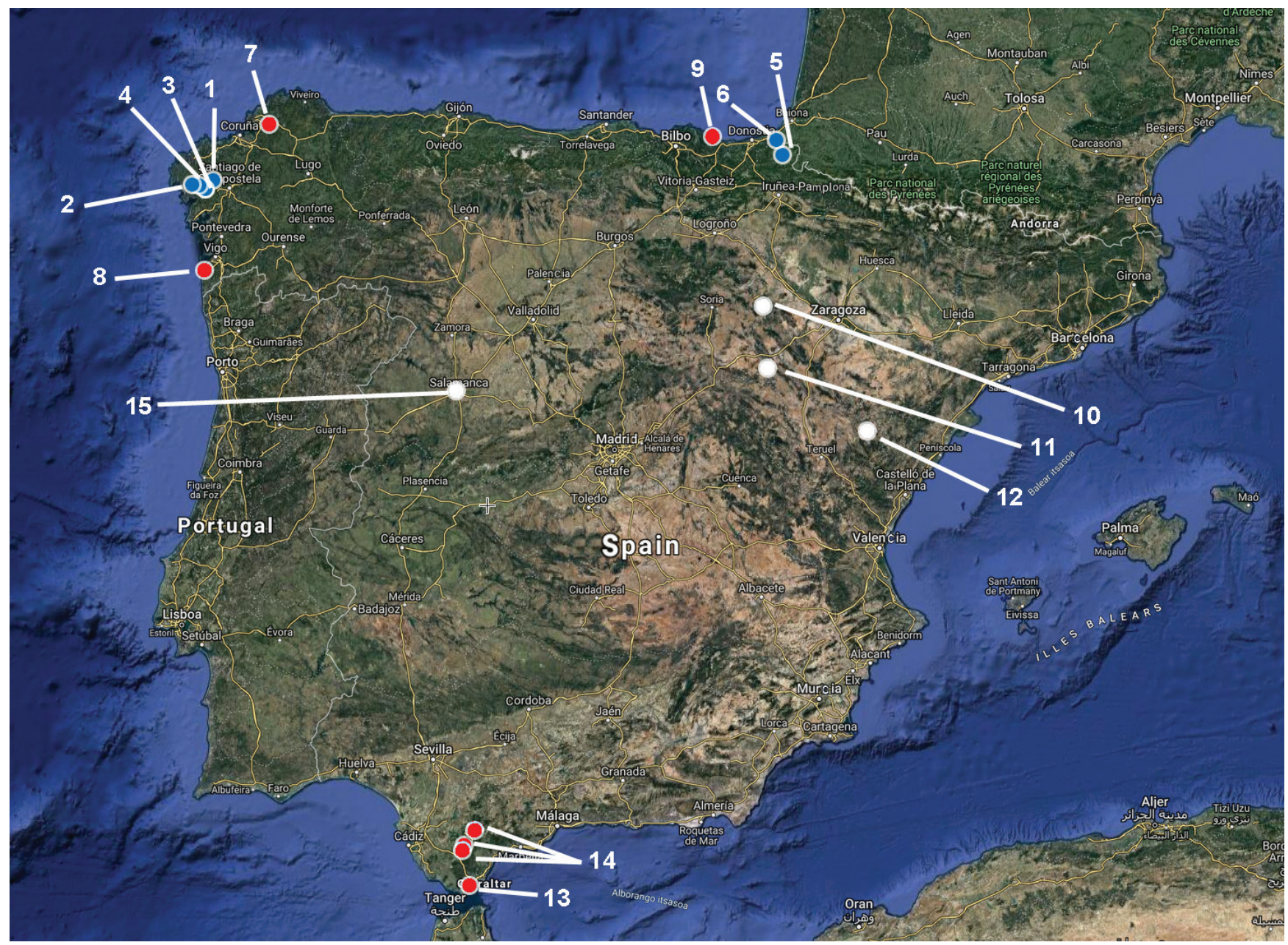

Fig. 1. Map of the 15 reports of the epiphytic macrolichen Pseudocyphellaria aurata with specific locality in mainland Spain. Type of records: newly discovered (blue), possibly extinct (red), unplausible localities (white). Localities are numbered as in the text.
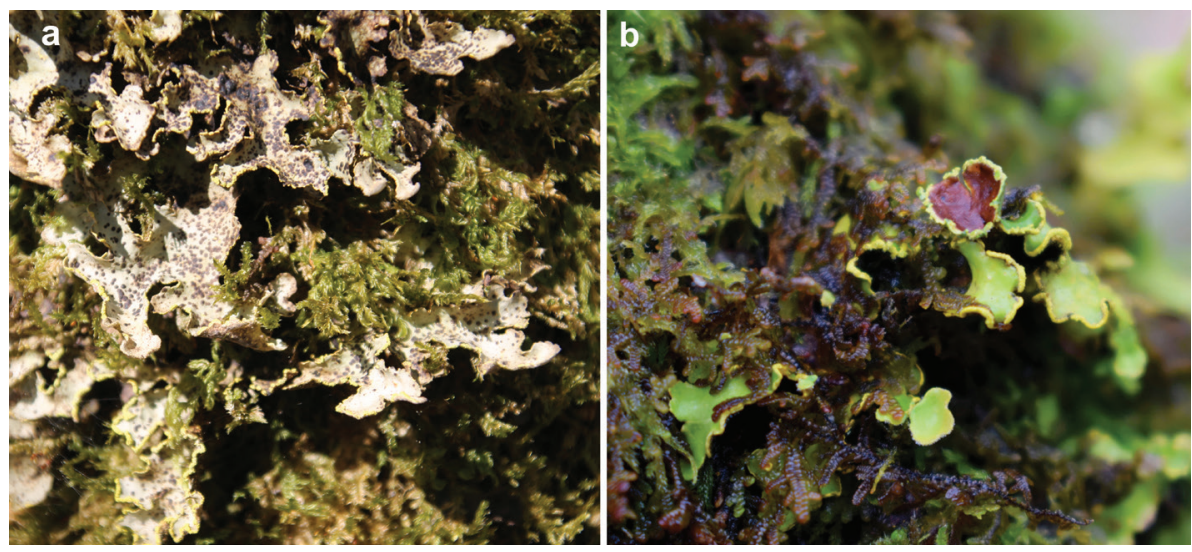

Fig. 2. Thallii of Pseudocyphellaria aurata in the field: a, Thallus of Pseudocyphellaria aurata showing infection by Arthonia pelvetii in Beba (A Coruña); $\mathbf{b}$, Thallus with an apothecium in Devesa de Anllares (A Coruña).

stations. The forest is composed mainly of Castanea sativa, Crataegus monogyna, Fraxinus excelsior L., and Quercus robur. We detected 31 thalli of Pseudocyphellaria aurata on bark of 7 different Quercus robur trees, although one of them was fallen; all the specimens were found on the southern or southwestern aspect. The number of thalli on the trees ranges 
between 1 to 10 , and with a size that varies from $0.5 \times 0.5$ to $16 \times 18 \mathrm{~cm}$. Most thalli had only soralia but one of them had an apothecium (Fig. 2b). Accompanying species, many of them with euoceanic affinities, were Hypotrachyna sinuosa (Sm.) Hale, Leucodermia leucomelos, Ricasolia amplissima (Scop.) De Not. (Dendriscocaulon umhausense (Auersw.) Degel. state), Ricasolia virens (With.) H.H.Blom \& Tønsberg, Lobaria pulmonaria (L.) Hoffm. (abundant with apothecia), Nephroma tangeriense, Normandina pulchella, Pannaria rubiginosa (Ach.) Bory, Parmeliella triptophylla, Pectenia cyanoloma (Schaer.) P.M.Jørg., L.Lindblom, Wedin \& S.Ekman, P. plumbea, Sticta limbata, Sticta sylvatica (Huds.) Ach., Teloschistes flavicans, and ferns such as Dryopteris guanchica Gibby \& Jermy, and Hymenophyllum tunbrigense (L.) Sm.

4. Santa Leocadia, Mazaricos, A Coruña, Galicia. $300 \mathrm{~m}$, $2243 \mathrm{l} / \mathrm{m}^{2}, 12.2^{\circ} \mathrm{C}$ (Coto Muíño station). This population is located along the Vao da Denonciña stream in a deep valley. The riparian forest along the stream harbours euoceanic ferns such as Hymenophyllum tunbrigense and Woodwardia radicans (L.) Sm. The forest is composed mainly of Corylus avellana, Crataegus monogyna, Fraxinus excelsior, Laurus nobilis L., and Quercus robur. Main accompanying species were: Leucodermia leucomelos, Lobarina scrobiculata, Nephroma tangeriense, Normandina pulchella, Pannaria rubiginosa, Parmeliella triptophylla, Sticta limbata, and $S$. sylvatica. Three subpopulations were found in this locality (Table 1): Santa Leocadia 1, where we found eight thalli on six trees, four Corylus avellana and two Laurus nobilis trees, respectively. Santa Leocadia 2, with two thalli on a Corylus avellana tree and two more on a Quercus robur tree. Santa Leocadia 3, with seven thalli on two $Q$. robur trees, from the base up to a height of c. $4 \mathrm{~m}$ in one of the trees.

5. Bertiz Natural Park, Bertizarana, Navarra. 200-230 m, $1508 \mathrm{l} / \mathrm{m}^{2}, 15.2^{\circ} \mathrm{C}$ (Iñarbegi NG station). This protected area has been poorly managed since the late Middle Age and it constitutes one of the better-preserved old-growth forests in the northern Iberian Peninsula and southern Europe. Nearly the entire reserve is covered by beech (Fagus sylvatica L.) and oak (Quercus robur) forest, with an abundant presence of pollard-trees and riparious vegetation along its numerous streams. We have detected the presence of Pseudocyphellaria aurata in two spots along Aranea stream along the track towards Plazazelai, $500 \mathrm{~m}$. apart from each other. Two subpopulations were found at this locality (Table 1): Bertiz 1 , where we found two thalli (one big and sorediate; the other one small), found in April 2015 on the bark of Salix atrocinerea Brot., with presence of Leptogium brebissonii Mont., Pannaria conoplea, P. rubiginosa and Sticta fuliginosa, small thalli of Ricasolia virens and abundant Lobaria pulmonaria and Frullania sp. The Salix tree is located near a track and is rather sun-exposed and is rather old with numerous dead branches colonized by the polypore Daedaleopsis tricolor (Bull.) Bondartsev \& Singer (Fig. 3). Two years later (23 December 2017) no thalli of P. aurata were found on the same tree, so we suspect that this subpopulation may have gone extinct. The other subpopulation is Bertiz 2, where we could see at least four thalli on a medium-sized Alnus glutinosa (L.)Gaertn. almost devoid of other lichens at the base. However, thalli of $P$. aurata grew at 6-8 m height with other lichens like Hypotrachyna revoluta (Flörke) Hale and Lobaria pulmonaria. One of the thalli was large (c. $15 \mathrm{~cm}$ diam.) and in good shape. This trunk was broken and hanging by the middle and the thalli of Pseudocyphellaria were then at 1-2 $\mathrm{m}$ high. As this tree was about to fall down, four small lobules were translocated to other trees in the vicinity with similar conditions. Their evolution has not been checked yet.

6. Intzola erreka, Basque Municipal Community, Pyrenées atlantiques, France; Bera-Vera de Bidasoa, Navarra. 110 $200 \mathrm{~m}, 1857 \mathrm{l} / \mathrm{m}^{2}, 13.2^{\circ} \mathrm{C}$; obtained from Bera-Larrategaña station). This population is located c. $1 \mathrm{~km}$ E from Ibardin pass, along Intzola stream. The upper $1.5 \mathrm{~km}$ of Intzola stream is in Spain and it crosses the border with France before merging with Urdazuri-Nivelle river several kilometres downstream. Jovet referred (1941) to this site $500 \mathrm{~m}$ far from the milestones 18 and 19 delimiting the Spanish-French border as "ravin de Berra", which is seemingly a misspelling of "Bera". The actual name of the stream running between milestones 18 and 19 is Intzola or Izola (Capdevila i Subirana 2009). The zone has large deforested areas intermixed with forest stands with scattered large pollard oak trees (Quercus robur) and riparious vegetation with Alnus glutinosa, Fraxinus excelsior, Corylus avellana, and Salix atrocinerea, along with scattered planted Platanus hispanica trees. Two subpopulations were documented (Table 1): Intzola 1, which is the site reported by Jovet (1941), located where Intzola stream and a smaller tributary descending from Ibardin merge. We detected $P$. aurata in two non-pollarded $Q$. robur trees, in a rather open and light-exposed location (Fig. 4a-b). One of the trees harboured 10 thalli of $P$. aurata dispersed from the base up to a height of c. $8 \mathrm{~m}$. Accompanying mosses and lichens are Coenogonium luteum (Dicks.) Kalb \& Lücking, Flavoparmelia caperata (L.) Hale, Leptogium sp., Ricasolia virens, Parmeliella tryptophylla, Parmotrema perlatum (Huds.) M. Choisy, Pertusaria pertusa (L.) Tuck., Pertusaria flavida (DC.) J.R.Laundon, Sticta fuliginosa, Brachythecium sp., Frullania sp., Homalothecium sericeum (Hedw.) Schimp., Hypnum cupressiforme Hedw., Neckera complanata (Hedw.) Huebener, and Zygodon viridissimus (Dicks.) Brid. A second tree was hollow and burnt inside. This tree hosted 23 thalli. Accompanying species: Flavoparmelia caperata, Ricasolia virens, Normandina pulchella, Parmotrema crinitum (Ach.) M.Choisy, Nephroma laevigatum, Pertusaria sp., Brachythecium sp., Metzgeria furcata (L.) Corda, Neckera crispa Hedw., and Zygodon viridissimus (Fig. 5). Jovet (1941) described that thalli of Pseudocyphellaria aurata grew on several oak trees ("plusieurs Chênes"). Despite our efforts, 80 years later, $P$. aurata has only been spotted in two trees indicating that the number of colonized trees is probably in decline. The specimen collected by Jovet is deposited in PC (PC 0072622).

The second subpopulation is Intzola 2, located c. $1.7 \mathrm{~km}$ upstream, where two Platanus hispanica trees with large 

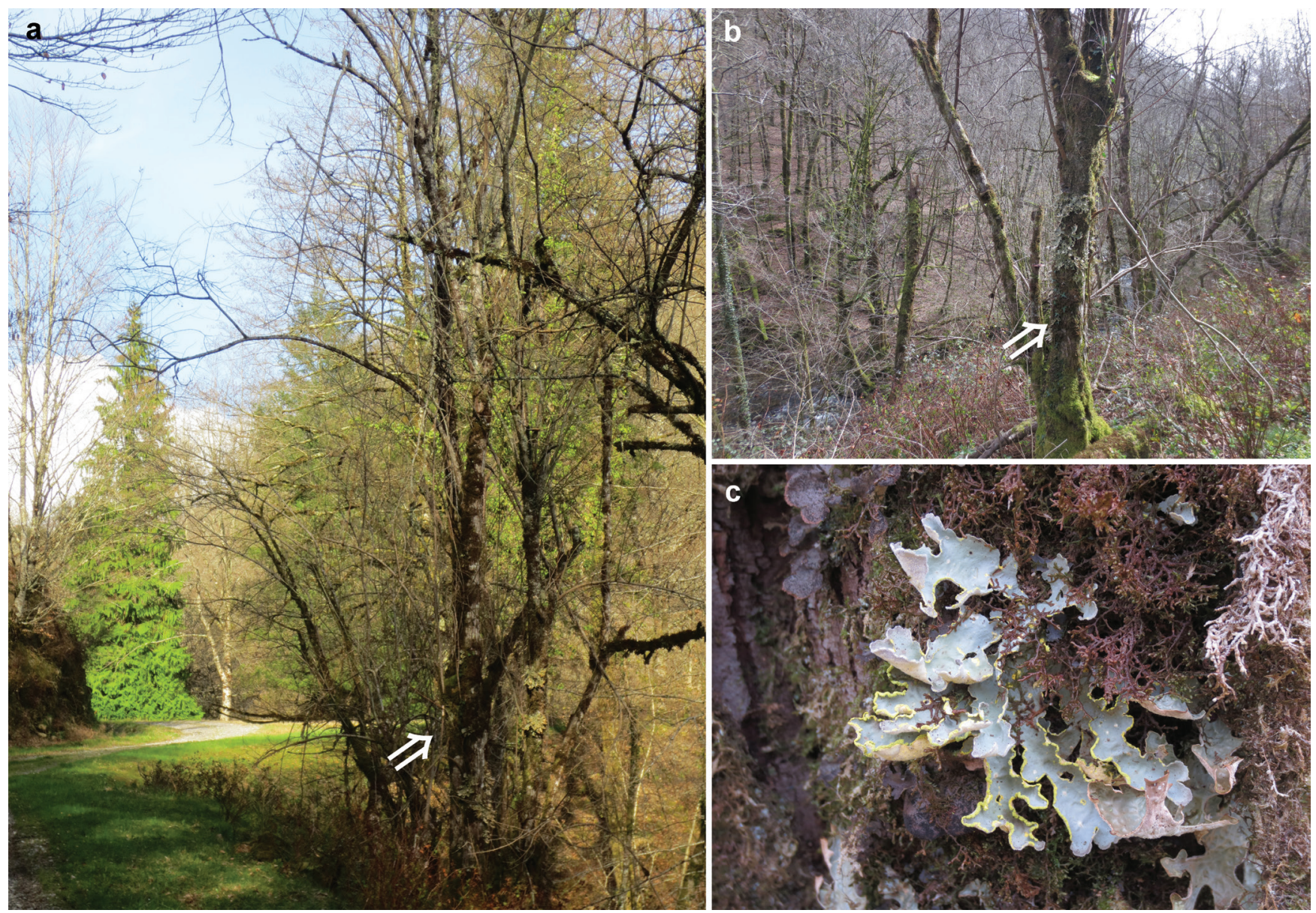

Fig. 3. Subpopulation Bertiz 1, Navarra: a, Tree where Pseudocyphellaria aurata was located; b, Same tree from the opposite perspective; c, Sorediate thalli of $P$. aurata. Arrows indicate the spot where thalli of $P$. aurata grew.

thalli of Lobaria pulmonaria (Fig. 4c-d) stand out. One of these trees hosts c. 64 thalli of Pseudocyphellaria aurata. A few more thalli were found on the ground around the tree base, attached to detached bark pieces. Accompanying species were: Lobaria pulmonaria, Ricasolia virens, Nephroma laevigatum, Brachythecium sp., Eurhynchium praelongum (Hedw.) Schimp., Metzgeriafurcata, Isothecium myosuroides Brid., and Neckera complanata (Hedw.) Huebener.

\section{Previous localities}

Burgaz \& Martínez (1999, 2003) reported Pseudocyphellaria aurata only from A Coruña in Spain and from three provinces in Portugal. However, P. aurata has been cited from more localities, and other specimens from Spain exist also in herbaria. Detail examination all these previous reports is of paramount importance to assess a possible decline of $P$. aurata in the Iberian Peninsula, and for the application of the criteria of the IUCN. Thus, we provide below a commented list of 11 previous reports of $P$. aurata in mainland Spain, listed from most recent to oldest. Most of these records were not included in Burgaz \& Martínez (1999, 2003). Localities are also represented on a map (Fig. 1).
7. Caaveiro, Fragas do Eume Natural Park, A Coruña, Galicia. This locality was first reported by Carballal \& al. (1985), based on a specimen collected in 1978 made by an unknown collector (SANT-Lich 133). Population size was not reported. Pseudocyphellaria aurata has not been observed again at this site, although the locality has been often visited (López de Silanes, pers. comm.). Fragas do Eume Natural Park is a well preserved and protected coastal deciduous forest, where habitat loss or degradation should not have caused decline or extinction of $P$. aurata during the past 40 years. Nevertheless, the lack of recent observations suggests that population size of $P$. aurata is very small, or even, that the species might have become extinct.

8. Bayona, Pontevedra, Galicia. A correctly identified specimen of Pseudocyphellaria aurata collected by Lázaro Ibiza is kept at the MAF herbarium (MAF-Lich 12139), but to our knowledge, this locality was never reported in his publications. Although there are no recent reports of $P$. aurata from Pontevedra, we consider the presence of $P$. aurata there very likely in the past due to suitable climatic conditions. This population, however, is likely to have disappeared as a result of habitat degradation. 

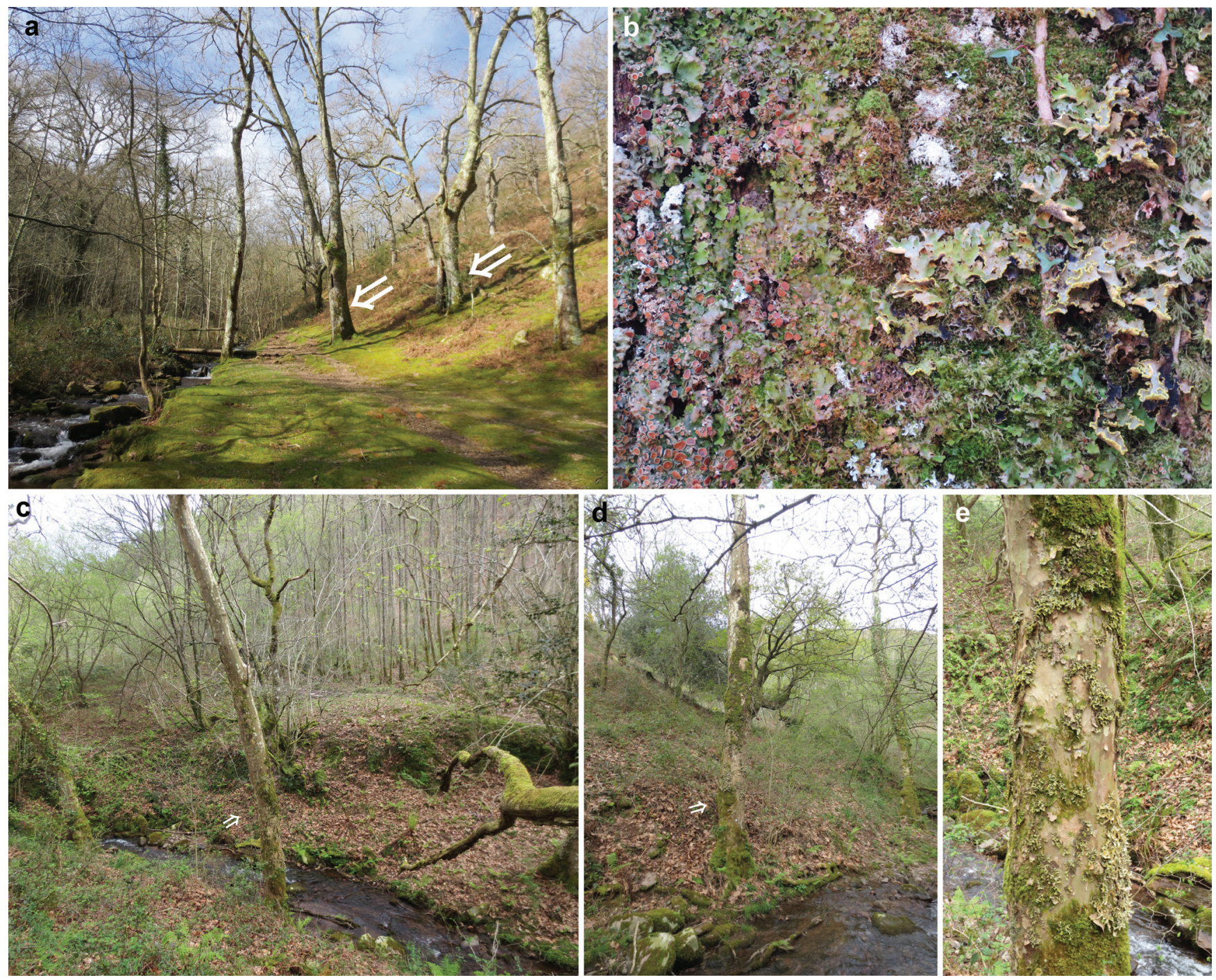

Fig. 4. Population Intzola, Navarra: a, Trees where Pseudocyphellaria aurata was located in Intzola 1 subpopulation; b, Thalli of $P$. aurata growing together with Ricasolia virens in subpopulation Intzola 1; c, Tree where $P$. aurata grew in subpopulation Intzola 2; d, Same tree from another perspective; d, Close-up showing thalli of $P$. aurata growing on loose bark of Platanus hispanica. Arrows indicate trees on which thalli of P. aurata grew.

9. Lekeitio (Biscay). Jovet (1941), apparently after a communication by P. Allorge, indicated that Pseudocyphellaria aurata was found "sur des Quercus dans des ravins maritimes accidentés à $25 \mathrm{~m}$. de la mer, 1933". Regrettably, no herbarium specimen supports this finding. This is a botanically remarkable locality because of the presence of rich stands of Woodwardia radicans and Stegnogramma pozoi (Lag.) K.Iwats. (Allorge \& Allorge 1941), which are associated to warm hyperoceanic climates. Etayo (2009) visited this locality and could not find $P$. aurata there. Recently, we visited all the ravines that had forest in 1945 (Egurbideko erreka, Portuko erreka, Burgañeko erreka) covering the area between Lekeitio and Ondarroa, where P. Allorge and V. Allorge have made collections. At present, those ravines present patches of rather degraded forest with few mature oak trees, where we could not find $P$. aurata or any species of the Lobarion communities. We consider the presence of $P$. aurata in this locality feasible in the past, but it appears to have gone extinct due to habitat loss and degradation.

10. Moncayo (Zaragoza, La Rioja or Soria). This location was first cited by Colmeiro (1889) indicating "Láz." (Blas Lázaro e Ibiza) as the collector, and was later mentioned by Lázaro e Ibiza (1898) and Longinós Navás (1903, 1908). Interestingly, a specimen labelled as collected in Moncayo, without date, is kept in the Lázaro e Ibiza herbarium (MAFLich 12135). The presence of $P$. aurata in Moncayo is unlikely since the continental climate with cold winters is unsuitable for P. aurata and for other more common species of the Lobarion alliance. However, this specimen represents beyond doubt $P$. aurata. Pseudocyphellaria aurata has not been observed in Moncayo again and we thus propose that the locality given in the label is incorrect. 
11. Monasterio de Piedra (Zaragoza). A specimen collected by Lázaro e Ibiza in 1894 is kept in the MAF herbarium (MAF-Lich 111914). Lázaro e Ibiza omitted this locality in his account of Spanish lichens in 1898 . The specimen cited above represents $P$. aurata beyond doubt, but no later observation of this species could be traced in Monasterio de Piedra. As in the previous case, the presence of $P$. aurata in this continental locality is difficult to conceive and we propose that the label locality of the specimen is incorrect.

12. Villarluengo (Teruel). This locality was mentioned by Colmeiro (1867) citing "Xarne" (Agustín Xarne) as the collector. This information might have been obtained from an unpublished list of plants by Xarne ("Plantas observadas en este término de la villa de Villarluengo"), but there are not specimens supporting it. We regard this record as very doubtful due to the oceanic requirements of $P$. aurata and we propose that it might be a misidentification.

13. Algeciras, Cádiz. This record corresponds to a herbarium specimen collected by Bourgeau, without date, deposited in PC (PC 0072591). This specimen was probably collected in 1849 or 1853 when E. Bourgeau (1815-1877) visited Andalusia (Carrasco \& al. 2002) and was later included by Jovet (1941) in his locality list. The specimen represents undoubtedly $P$. aurata, and is the only one known from southern mainland Spain. Pseudocyphellaria aurata is probably extinct in this area. The species has not been detected in Andalusia (Burgaz 2014) since Bourgeau's record, despite several lichen field surveys conducted in the Algeciras area.

14. Alcalá de los Gazules and Ubrique (Cádiz), Sauceda de Cortes (Málaga). These three localities were also listed by Colmeiro (1867) citing "Clem." (Simón de Rojas Clemente) as collector. These localities were probably obtained by Colmeiro through an unpublished manuscripts by Clemente, or from private correspondence. Degelius (1935) also included these localities in his distribution map of $P$. aurata. Regrettably, most part of the Clemente herbarium is lost (González Bueno \& Rico 1991) and specimens from these localities are not available. Two of us visited Alcalá de los Gazules and Sauceda de Cortes in March 2018, and although well-preserved Lobarion communities were observed in Sauceda de Cortes, $P$. aurata could not be found. As we have seen material of $P$. aurata from Algeciras, we consider these reports are likely to be correct. Although $P$. aurata might be extinct in the area, it should be searched for again in these localities.

15. Salamanca area. This area was marked by Degelius (Fig. 43, 1935) with an empty point on the map of Pseudocyphellaria aurata. According to our search, empty points refer to reports without a specific location and we thus suspect the source of Degelius was Lázaro e Ibiza (1920), who mentioned P. aurata in "C., S. y O." of Spain. Although, Jovet (1941) also mentioned this locality, we think it is likely erroneous.
16. Without locality. Colmeiro (1867) listed Lagasca as the collector of this specimen of Pseudocyphellaria aurata. Nevertheless, this report seems to correspond to Pseudocyphellaria crocata, as Colmeiro merged $P$. aurata and $P$. crocata into a single species. We have checked the Spanish specimen sent by Lagasca and seen by Acharius (1810), identified as $P$. crocata (H-Ach without number). No other collection of $P$. crocata has been made in Spain ever since and this suggests, if the country information is correct and the specimen of $P$. crocata was indeed collected in Spain, it is very possible to have become extinct in continental Spain. An alternative is that the Spanish specimen was collected in the Canary Islands, where $P$. crocata is not rare, but Lagasca is not known to have travelled there.

17. Without locality. Fries (1831) listed $P$. aurata from Spain based on a specimen collected by L. Dufour, who travelled to Spain in 1826 (Fries 1831). However, no specimen supporting this report could be traced in the Fries herbarium (UPS-Fries).

\section{DISCUSSION}

Examination of bibliographic and herbarium data yielded new and noteworthy information on Pseudocyphellaria aurata in peninsular Spain. In addition, six new localities were discovered after a focused search in suitable habitats and this suggests that more not-yet-discovered localities might exist. In one of them, a thallus with a single apothecium was found, which represents, as far as we know, the first fertile specimen ever observed in Europe. On the other hand, the existence of a number of herbarium specimens and bibliographic reports during the $19^{\text {th }}$ century suggest that $P$. aurata was considerably more widespread in Spain in the past.

This study confirms that Pseudocyphellaria aurata is not extinct in mainland Spain, where it had not been seen since 1978, nor has it become extinct in the Pyrenees. Considering that $P$. aurata is an eye-catching, easily recognizable macrolichen, the number of new localities found is remarkable. All newly discovered localities constitute well-preserved patches of Atlantic forest along streams, in areas with strong oceanic influence and mild winters. Forests where $P$. aurata was found have had ecological continuity but have been exploited in the past as suggested by the presence of pollarded trees. The presence of $P$. aurata on a planted Platanus hispanica suggests that $P$. aurata is also able to grow in somewhat disturbed forest patches. Atlantic deciduous forests, the exclusive habitat of extant populations of $P$. aurata in Spain, have undergone a strong decline due to human pressure, forestry and crop establishment (Blanco \& al. 1998) and $P$. aurata has probably declined likewise. Forest patches were $P$. aurata is now found are in general small, fragmentary, and harbour small populations of $P$. aurata, with few trees colonized and few individuals. Except for the Bertiz population, a large (2040 ha) nature reserve of remarkably well-preserved deciduous forest, forestry is an important threat for known populations of $P$. aurata. Extant populations 
of $P$. aurata have, as small populations usually do, a higher risk of extinction. Dynamics of populations of $P$. aurata are difficult to assess due to lack of data, but the number of trees colonized by $P$. aurata seems to have decreased in Intzola 1 subpopulation; Jovet (1941) saw P. aurata in several oak trees but it is currently present only in two.

The critical analysis of previous records found in the literature and herbarium specimens suggests that the distribution area of Pseudocyphellaria aurata has been reduced and that local extinctions have occurred. The species is distributed in areas of temperate oceanic climate and mild winters in Europe (Sérusiaux 1989). Thus, reports from Lekeitio (Biscay) and Bayona (Pontevedra), this last supported by a herbarium specimen, support the availability of suitable areas for $P$. aurata climate-wise. At least in Lekeitio, and probably also in Bayona, populations appear to have gone extinct due to habitat loss or degradation. The presence of $P$. aurata in Andalusia in the past, supported by the Bourgeau specimen at PC (PC0072591), seems also very likely.

The narrow ravines present in some areas of Cádiz and Málaga provinces, characterized by oceanic influence, high humidity and warm temperatures, host populations of several species of vascular plants of Ibero-macaronesian distribution (Fernández-Palacios \& al. 2011), macrolichens of the Lobarion communities (Sequeiros Ugarte \& al. 1986), and are deemed suitable for P. aurata as well. Thus, all the previous Andalusian records are probably correct, but due to the lack of finds or reports in the last 170 years and to our unfruitful attempts to find the species in Cádiz and Málaga, we suggest that $P$. aurata might have become extinct in Andalusia. In contrast, reports of $P$. aurata from central Spain (Moncayo, Monasterio de Piedra, Villarluengo) are considered here erroneous, since climatic characteristics in that area, continental climate with cold winters, do not satisfy the requirements of $P$. aurata.

Monitoring of known populations is necessary to detect trends in population dynamics and to be able to apply the IUCN criteria more accurately. Considering its very plausible decline over the past 200 years, small population size and the low number of trees colonized, P. aurata is a threatened species that needs to be protected in Spain. A preliminary assessment based on the data presented here assigned the Critically Endangered category to P. aurata in Spain (Atienza \& al. 2019) and conservation initiatives should be implemented to avoid its extinction. However, the known extant populations should be monitored and protected to guarantee their conservation and to prevent them from extinction due to catastrophic stochastic events. Population restoration through transplantation of individuals to uncolonized trees is a possibility that proved successful in Japan with $P$. aurata (Kon \& Ohmura 2014). We hope to stimulate fieldwork in search for $P$. aurata, in localities where it has previously been reported and in potentially new localities to obtain a more accurate picture of its current state in Spain. Likewise, we consider it necessary to assess the present status of $P$. aurata at a European scale and following the criteria of the International Union for Conservation of Nature (IUCN), for which the present account of Spanish populations will be helpful.

\section{ACKNOWLEDGEMENTS}

We wish to thank José Pizarro (MAF) and Leena Myllys (H) for kindly sending us scans of historical material or specimens on loan.

\section{REFERENCES}

Acharius E. 1810. Lichenographia universalis. Gottingen, Germany. Allorge V. \& Allorge P. 1941. Les ravins à Fougères de la corniche vascocantabrique. Bulletin de la Société Botanique de France 88: 92-111.

Atienza V., Fos S., Burgaz A.R., López de Silanes M.E., Millanes A., Olariaga I., Paz-Bermúdez G., Pérez-Vargas I., Prieto M. \& PérezOrtega S. 2019. Contribution to assessment of threatened species in red list of lichen-forming and lichenicolous fungi in Spain and Portugal. XXII Symposium of Cryptogamic Botany, Lisbon 24-26 July 2019. Book of abstracts.

Baillie E.M., Hilton-Taylor C. \& Stuart S. N. 2004. 2004 IUCN Red list of threatened species. A Global species assessment. IUCN, Gland, Switzerland and Cambridge, UK.

Blanco E., Casado M.A., Costa M., Escribano R., García M., Génova M., Gómez A., Gómez F., Moreno J.C., Morla C., Regato P. \& Sainz H. 1998. Los bosques ibéricos: una interpretación geobotánica. Editorial Planeta, Barcelona.

Benítez Á., Prieto M., González Y. \& Aragón G. 2012. Effects of tropical montane forest disturbance on epiphytic macrolichens. Science of the Total Environment 441: 169-175.

Burgaz A.R. 2014. Líquenes de Andalucía (S de España): catálogo bibliográfico y nuevos datos del NW del área. Botanica Complutensis 38: 53-88.

Burgaz A.R. \& Martínez I. 1999. La familia Lobariaceae en la Península Ibérica. Botanica Complutensis 23: 59-90.

Burgaz A.R. \& Martínez I. 2003. Flora Liquenológica Ibérica. Peltigerales: Lobariaceae, Nephromataceae, Peltigeraceae. Sociedad Española de Liquenología. Murcia.

Capdevila i Subirana J. 2009. Historia del deslinde de la frontera hispanofancesa. Centro Nacional de Información Geográfica. Dirección general del Instituto Geográfico Nacional. www.ub.edu/gehc/pdf/ Deslinde.pdf

Carballal R., López de Silanes M.E. \& Bahillo L. 1985. Fragmenta Chrorologica Occidentalia (Lichenes), 46-72). Anales del Jardín Botánico de Madrid 42: 236-238.

Carrasco M.A., Perea D., Arroyo M., Carramolino M.S. \& Quintana A. 2002. La colección «Plantes d'Espagne, 1849» de Eugène Bourgeau, en el herbario del Real Colegio Alfonso XII de San Lorenzo de El Escorial, Madrid (España). Botanica Complutensis 27: 137-146.

Casas C., Brugués M., Cros R.M. \& Sérgio C. 2006. Handbook of mosses of the Iberian Peninsula and the Balearic Islands. Institut d'Estudis Catalans, Barcelona.

Casas C., Brugués M., Cros R.M., Sergio C. \& Infante M. 2009. Handbook of liverworts and hornworts of the Iberian Peninsula and the Balearic Islands. Institut d'Estudis Catalans, Barcelona.

Colmeiro M. 1867. Enumeración de las Criptogamas de España. Parte segunda. Talógenas: Hongos, Líquenes, Collemaceas, Algas. Revista de los Progresos de las Ciencias 17-18: 1-260.

Colmeiro M. 1889. Enumeración y revisión de las plantas de la Península Hispano-Lusitana é Islas Baleares. Tomo V. Monocotiledóneas y criptógamas. Imprenta de la Viuda e hija de Fuentenebro. Madrid.

Consellería de Medio Ambiente e Desenvolvemento Sostible. 2007. Decreto 88/2007 do 19de abril, polo que se regula o Catálogo galego de especies amenazadas. Diario oficial de Galicia 89: 7409-7423.

Degelius G. 1935. Das Ozeanische Element der Strauch- und Laubflechtenflora von Skandinavien. Acta Phytographica Suecica 7: $1-411$.

Etayo J. 1989. Líquenes epifitos del norte de Navarra. Tesis Doctoral ined. Univ. de Navarra. Pamplona.

Etayo J. 2002. Revisión del herbario de líquenes del P. J. M. Lacoizqueta. Naturzale 17: 5-34. 
Etayo J. 2009. Líquenes y hongos liquenícolas del País Vasco. Ihobe, Sociedad Pública del Departamento de Medio Ambiente, Planificación Territorial, Agricultura. Bilbao.

Fernández-Palacios J.M., de Nascimento L., Otto R., Delgado J.D., García del-Rey E., Arévalo J.R. \& Whittaker R.J. 2011. A reconstruction of Palaeo-Macaronesia, with particular reference to the long-term biogeography of the Atlantic island laurel forests. Journal of Biogeography 38: 226-246.

Fries E.M. 1831. Lichenographia Europaea Reformata. Lund, Sweden.

Galloway D.J. 1998. Studies on the lichen genus Sticta (Schreber) Ach.: V. Australian species. Tropical Biology 15: 117-160.

Galloway D.J. \& Arvidsson L. 1990. Studies in Pseudocyphellaria (lichens) II. Ecuadorean species. The Lichenologist 22: 103-135.

González Bueno A. \& Rico V.J. 1991. La introducción de las teorías de E. Acharius (1757-1819) en la liquenología española. Acta Botanica Malacitana 16: 141-148.

Hayward G.D. \& Rosentreter R. 1994. Lichens as nesting material for northern flying squirrels in the northern Rocky Mountains. Journal of Mammalogy 75: 663-673.

IUCN. 2015. The IUCN Red List of Threatened Species. Version 2015-4 (accessed 05.04.2016) www.iucnredlist.org.

Jovet P. 1941. Le Pseudocyphellaria aurata (Ach.) Vain. (Sticta aurata Ach.) dans les Pyrénées basques. Bulletin de la Société Botanique de France 88: 197-210

Kon Y. \& Ohmura Y. 2014. Regeneration of Pseudocyphellaria aurate transplanted on a tree in Japan. The Lichenologist 46: 833-836.

Lázaro B. 1898. Nota sobre algunos líquenes de España y Portugal (1). Actas de la Sociedad Española de Historia Natural 1898: $200-205$.

Lázaro e Ibiza B. 1920. Compendio de la Flora Española. Tercera edición. Imprenta clásica Española. Madrid.

Longinós Navás E.P. 1903. Líquenes del Moncayo recogidos en la excursión que verificó la Sociedad Aragonesa de Ciencias Naturales. Boletín de la Sociedad Aragonesa de Ciencias Naturales 2: 75-77.
Longinós Navás E.P. 1908. Líquenes de Aragón. Anales de la Facultad de Ciencias de Zaragoza 2: 107-123.

Matos P., Pinho P., Aragón G., Martínez I., Nunes A., Soares A.M.V.M. \& Branquinho C. 2015. Lichen traits responding to aridity. Journal of Ecology 103: 451-458.

Moncada B., Lücking R. \& Betancourt Macuase L. 2013. Phylogeny of the Lobariaceae (lichenized Ascomycota: Peltigerales), with a reappraisal of the genus Lobariella. The Lichenologist 45: 203-263.

Nimis P.P. 1993. The lichens of Italy. An annotated catalogue. Torino, Museo Regionale di Scienze Naturali, Monografie XII.

Nimis P.L. \& Martellos S. 2017. ITALIC - The Information System on Italian Lichens. Version 5.0. University of Trieste, Dept. of Biology. http://dryades.units.it/italic.

Roux C., Signoret J. \& Masson D. (viewed on 1 April 2016). Proposition d'une liste d'espèces de macrolichens à protéger en France. Association française de lichénologie. Unpublished.

Scheidegger C. \& Werth S. 2009. Conservation strategies for lichens: insights from population biology. Fungal Biology Reviews 23: 55-66.

Sequeiros Ugarte M.V., García Rowe E.J. \& Silvestre Domingo S. 1989 Aportación al conocimiento de los líquenes epífitos de la provincia de Cádiz, 1. Studia Botanica 5: 85-104.

Sérusiaux E. 1989. Liste rouge des macrolichens dans la Communauté européenne. Centre des recherches sur les lichens, Université de Liège.

Smith C.W., Aptroot S., Coppins B.J., Fletcher A., Gilbert O.L., James P.W. \& Wolseley P.A. 2009. The Lichens of Great Britain and Ireland. British Lichen Society. London.

Thiers B. 2020 [continuously updated]. Index Herbariorum. A global directory of public herbaria and associated staff. New York Botanical Garden's Virtual Herbarium. http://sweetgum.nybg.org/ih/.

Vivant J. 1988. Les lichens des Pyrénées occidentales françaises et espagnoles. Documents d'écologie pyrénenne 5: 3-119.

Woods R.G. \& Coppins B.J. 2012. A conservation evaluation of British Lichens and Lichenicolous fungi. Species status 13. Joint Nature Conservation Committee, Peterborough. 